\section{Academic Freedom and Human Rights: A Neglected Perspective}

\section{Joseph H. Saunders}

Joseph H. Saunders is Associate Counsel responsible for academic freedom research and advocacy at Human Rights Watch in New York. Address: 350 Fifth Avenue, 34th Floor New York, NY 10118-3299 USA. Phone: (212) 290-4700. Fax: (212) 736-1300.

$\mathrm{O}$ n May 26, 1998, the Serbian parliament abolished the centuries-old autonomy of Serbian universities. Under pressure from the Milosevic government, the parliament passed a law that deprives faculty members throughout Serbia of their long-held right to participate in the selection of rectors, faculty deans, and governing boards, and effectively cancels-subject to renegotiation-the contracts of all professors and other teaching staff. The most dramatic changes under the new law have taken place at the University of Belgrade, which in recent years has been a center of student protest and is home to a number of prominent faculty critics of the government. At least 15 faculty deans there have been replaced by members of Serbia's ruling political parties, including a number of highranking party officials. Professors critical of government policies have come under fire and protests against the new law have been violently dispersed.

In Cuba, two independent researchers, Dr. Felix A. Bonne Carcasses and Dr. Marta B. Roque Cabello, are among four leaders of a pro-democracy group who have been imprisoned for over a year for the peaceful expression of their views. Prior to the arrests, the group, called the Internal Dissidents' Working Group for the Analysis of the Cuban Socioeconomic Situation, had publicly urged Cubans to abstain from voting in the upcoming elections and had issued a paper titled "The Homeland Belongs to Everyone." The paper criticized an official Communist Party discussion paper on the Cuban economy, and argued that greater democratization is a prerequisite to effective economic liberalization.

In 1997, Dr. Ahmed Subuh, a professor of education at al-Azhar University in Gaza, was arrested at his home by Palestinian Authority security forces and held in detention for over four months. The arrest came shortly after Dr. Subuh had administered an examination to students in which, among nine short essay questions asking students to analyze the interplay between social and educational problems, he included a question asking students to address the impact of corruption in either the university administration or the Palestinian Authority. Security forces subsequently raided Dr. Subuh's home and seized the exam papers of the students.

In dozens of countries, academics continue to be targeted when they publicly criticize government authorities, are active in political opposition parties or citizens' groups, or seek to investigate subjects deemed "politically sensi- tive" by the authorities. Reprisals against such individuals include censorship, denial of the right to travel to international conferences, arbitrary dismissal, and, in the worst cases, imprisonment and torture. Due to the high public profile of universities and of the academics who are involved, such attacks often play an exemplary role, serving as a warning to individuals throughout society that dissent and political opposition will not be tolerated. As George P. Hagan has noted: "Universities and academics owe it to themselves to minimize their political involvement. But it is hard to expect academics to remain politically neutral when their rights as citizens might well be at stake if they remained aloof from direct and active political involvement." ${ }^{1}$ When academics do speak out, their colleagues should defend their right to do so. The fact that relations between the university and the government are delicate, or that the government pays the salaries of university staff, should not be an excuse for inaction.

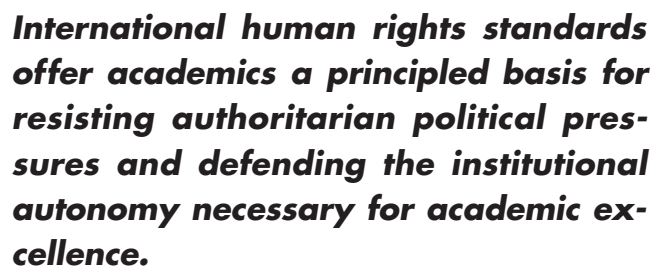

In many cases, it is not merely an individual student or academic who is targeted, but the university itself. In principle, the university is an institution open to all on the basis of merit, and should serve as an important intellectual resource not only to governments and industry, but also to individuals and interests independent of the state. In practice, as in Serbia today, attacks on campus-based critics and politically motivated government interventions often threaten to turn the university into an institution that exclusively serves the interests of state authorities.

International human rights standards offer academics a principled basis for resisting authoritarian political pressures and defending the institutional autonomy necessary for academic excellence. ${ }^{2}$ The most directly relevant right is freedom of expression, which includes "freedom to seek, receive and impart information and ideas of all kinds, regardless of frontiers." "' This is the bedrock of academic freedom. A university fulfills its mission when academics are not forced to support an official line, an economic agenda, or a political ideology, but rather are free to use their talents to advance human knowledge and understanding.

Although pressures to limit critical inquiry and academic debate can come from diverse quarters, the arbi- 
trary exercise of government power continues to represent the most significant threat to the academic community. Because the great majority of universities around the world are public institutions or are dependent on government funding, and because such institutions typically are viewed by governments as "prime instruments of national purpose, ${ }^{\prime 4}$ governments have considerable power to influence what takes place on campus and an incentive to wield that power. Although one might have hoped that abuses would end with the cold war, experience has proven otherwise.

While many scientific associations have long had active human rights programs, little work is being done by academics in the humanities and social sciences. This may be slowly changing - new groups like the academic freedom committee of the Middle East Studies Association (based in the United States) have emerged in recent yearsbut there is still a pressing need for new commitments of time and resources. ${ }^{5}$ In particular, academics can and should make a contribution to public awareness and understanding of the values served by free expression. To date, international attention to this basic right has understandably emphasized artistic freedom and freedom of the press, essential attributes of a free society. Relatively little attention, however, has been paid to the crucial role played by academic institutions, dedicated to inquiry, information, and ideas, in preserving and giving meaning to the right.

By visiting or attempting to visit students and scholars in prison, raising money for their legal defense and medical needs, raising their cases with governments and international organizations, academics ensure that their colleagues are not forgotten. By joining with colleagues to speak out against politically motivated dismissals and other attacks on the autonomy of academic institutions, academics fulfill an important part of their mission as educators.

\section{Notes}

1. George P. Hagan, "Academic Freedom and National Responsibility in an African State: Ghana," in Academic Freedom in Africa, ed. Mahmood Mamdani and Mamadou Diouf, (Dakar, Senegal: Codesria; Oxford 1994), 57.

2. Both the "Lima Declaration on Academic Freedom and Autonomy of Institutions of Higher Education," adopted by the World University Service in 1988 as an international guidepost for the defense of academic freedom, and UNESCO's "Recommendation Concerning the Status of Higher Education Teaching Personnel," adopted in 1997, expressly recognize the intimate connection between academic freedom and protection of basic civil and political rights.

3. Article 19, International Convention on Civil and Political Rights.

4. Clark Kerr, The Uses of the University (Cambridge: Harvard University Press, 1995).

5. Much of this work is now available on-line. The academic freedom page on the Human Rights Watch website (www.hrw.org), periodically updated, includes a list of relevant links.

\section{Market Models, Managerial Institutions, and Managed Professionals}

\section{Gary Rhoades}

Gary Rhoades is professor and director, Center for the Study of Higher Education, University of Arizona, Tucson AZ 85721, USA.

$\mathrm{T}$ he trend throughout much of the world is movement toward a U.S., "market-based" model of higher education. A related development is an increased role for management within individual institutions. What is overlooked in the promotion of such public policy shifts is the implications for social relations and social stratification in the academy and in society. Market models and managerial institutions bring with them a restructuring and renegotiation of social relations such that faculty are increasingly managed, stratified professionals. Moreover, this privatized, corporate model of American higher education has similar implications for social relations and social stratification in society at large.

The market model of U.S. higher education privileges certain markets over others. Over the past two decades it has reflected Reaganomics. It is "supply-side" higher education, focused more on employer than on student markets, and more on the needs of large private, transnational employers than on the needs of medium and small private and public employers. Supply-side policies are more suited to global than to local, national, and regional economies. ${ }^{1}$

Such a model is ill-suited to enabling higher education to play a role in addressing current economic challenges. Two patterns define present economic developments: (1) increased polarization within (and among) societies, between haves and have-nots; and (2) the emergence of regional trading blocs. The supply-side market model of higher education has little to offer in the way of either mitigating socioeconomic polarization within countries or facilitating the balance of cooperation and competition among countries. Indeed, such neoliberal policies in U.S. higher education have exacerbated polarization in the academy, which is related to polarization in the broader economy. Monies are being disproportionately allocated to high-tech fields more than to fields with large numbers of students going into middle-class service and helping profession careers. The decline of various servicerelated fields in higher education such as social work, library science, nursing, and education corresponds to the decline of the middle class. Moreover, supply-side higher education undermines the support for various academic fields (e.g., foreign languages, humanities, social sciences, education) that are arguably central to effective cooperation among countries in regional trading blocs. In the United States, internationalization of the curriculum tends to mean the development of applied master's degree programs in business and engi- 